\title{
RHOU wt Allele
}

National Cancer Institute

\section{Source}

National Cancer Institute. RHOU wt Allele. NCI Thesaurus. Code C114326.

Human RHOU wild-type allele is located within 1q42.11-q42.3 and is approximately 102 $\mathrm{kb}$ in length. This allele, which encodes Rho-related GT P-binding protein RhoU, plays a role in signal transduction that modulates cytoskeletal organization and cell migration. 